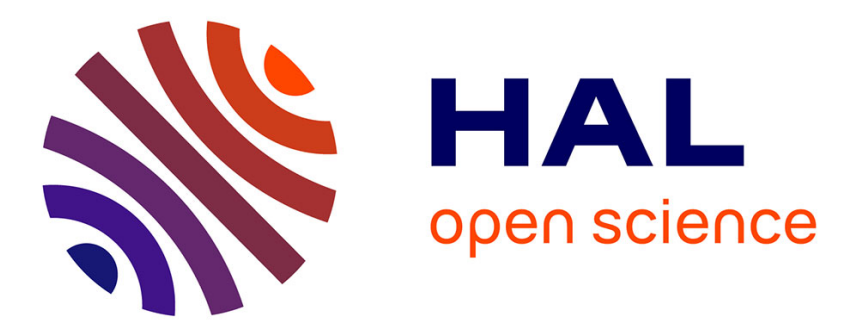

\title{
African Dust Observed over Canary Islands B Source-Regions Identification and Transport Pattem for some Summer Situations
}

Gilles Bergametii, Laurent Gomes, Genevieve Coude-Gaussen, Pierre Rognon, M.N. Lecoustumer

\section{- To cite this version:}

Gilles Bergametii, Laurent Gomes, Genevieve Coude-Gaussen, Pierre Rognon, M.N. Lecoustumer. African Dust Observed over Canary Islands $§$ Source-Regions Identification and Transport Pattem for some Summer Situations. Journal of Geophysical Research: Atmospheres, 1989, 94 (D12), pp.855-869. 10.1029/JD094iD12p14855 . hal-02326776

\section{HAL Id: hal-02326776 https://hal.science/hal-02326776}

Submitted on 22 Oct 2019

HAL is a multi-disciplinary open access archive for the deposit and dissemination of scientific research documents, whether they are published or not. The documents may come from teaching and research institutions in France or abroad, or from public or private research centers.
L'archive ouverte pluridisciplinaire HAL, est destinée au dépôt et à la diffusion de documents scientifiques de niveau recherche, publiés ou non, émanant des établissements d'enseignement et de recherche français ou étrangers, des laboratoires publics ou privés. 


\title{
African Dust Observed over Canary Islands : Source-Regions Identification and Transport Pattern for some Summer Situations
}

\author{
Gilles Bergametti AND LAURENT Gomes \\ Laboratoire de Physico-Chimie de l'Atmosphère, Université Paris 7 \\ Paris, France
}

Genevieve Coude-Gaussen ANd Pierre Rognon

Unité Associée 722, Centre National de la Recherche Scientifique, Université Pierre et Marie Curie

Paris, France

Michelle-Noelle Le Coustumer

Centre de Géomorphologie du Centre National de la Recherche Scientifique

Caen, France

\begin{abstract}
Bulk filtration samples of dust were collected on Fuerteventura (Canary Islands) in July 1985 in order to investigate African dust transport over this region during summer. Air mass trajectories and elemental and mineralogical analyses allowed us to distinguish between oceanic and continental influences: three African dust transport cases occured during this period. Geochemical and mineralogical tracers, combined with air mass trajectories, indicate that two different source regions of dust (Sahelian and Moroccan ones) are involved. Each of these exhibits specific $\mathrm{Si} / \mathrm{Al}$ and $\mathrm{Fe} / \mathrm{Al}$ ratios that can be considered as tracers of dust origin. A meteorological study, based on satellite imagery, meteorological maps, and air mass trajectories, confirms the previous identification of the source region. It is also possible to describe the meteorological situation controlling the atmospheric pathway of the dusts from the source regions up to the Canary Islands. This study suggests that some source regions (especially the Sahelian one) of dust affecting the Canary Islands during summer are rather different from the Moroccan ones observed in a spring situation by Coudé-Gaussen et al. (1987).
\end{abstract}

\section{INTRODUCTION}

During the last few years many authors have emphasized the major role that desert dusts play in various aspects of atmospheric physics and chemistry. For instance, it has been shown that the desert dusts significantly affect the optical properties of the atmosphere and consequently the general radiation budget of the Earth [Bach, 1976].Moreover, these particles have been recently invoked in cloud formation, although studies of the impact on precipitation processes have not been done. The incorporation of the desert dusts, which contain basic compounds such as calcite, in rainwater leads to an alkalination of rains, especially in European countries [Löye-Pilot et al., 1986; Schütz andKramer, 1987] where acidrains are a critical problem.

Another important feature concerning the desert dusts is the ability of the soil-derived particles less than $10 \mu \mathrm{m}$ in radius to undergo long-range transport [Tsoar and Pye, 1987]. The dust transport from northwestern Africa to the north tropical Atlantic and Caribbean Sea has been extensively investigated in the last two decades [Delany et al., 1967; Prospero and Carlson, 1972; Carlson and Prospero, 1972; Savoie andProspero, 1977; Buat-Ménard and Chesselet, 1979]. The African fingerprint of these dusts was detected even as far as $5000 \mathrm{~km}$ from their source [Prospero, 1981; Chester, 1986]. The ability of dusts to be transported long distan-

Copyright 1989 by the American Geophysical Union.

Paper number 89JD00979.

0148-0227/89/89JD-00979\$05.00 ces, along with the large quantity of matter injected into the atmosphere from desert areas (260 $\mathrm{Mt} \mathrm{yr}^{-1}$ for the African source [Schütz, 1980] means that the aeolian source is responsible for a large part of the deep-sea sedimentation in various oceanic regions of the Earth [Chester et al., 1979; Sarnthein et al., 1982; Uematsu et al., 1985; Rea and Jaenicke, 1982; Rea et al., 1985].

The Canary Islands are a particularly interesting environment in which to study the northern source regions of African dusts reaching both the North Atlantic and north western Europe. Very few studies have been conducted in the subtropical Atlantic regions, while the tropical Atlantic and the Mediterranean area [Chester et al., 1984; Prodi and Fea, 1979; Bergametti, 1987] are now well documented. An earlier study was performed in spring 1984 in order to characterize chemical and mineralogical properties of the desert dusts observed over Fuerteventura Island in relation to air mass trajectories and their source regions [Coudé-Gaussen et al., 1987].

The present study tries to investigate trajectories and source regions of dust observed over the subtropical eastern Atlantic during summer, when the regional atmospheric circulation is rather different. Geochemical and mineralogical indicators are used to investigate the origin of the dusts. We will then describe at a synoptic scale some summertime meteorological situations which control the changes in dust source regions.

\section{SAMpLNo and ANALYSIS}

The sampling site was at Corralejo $\left(29^{\circ} 12^{\prime \prime} \mathrm{N}, 13^{\circ} 30^{\prime \prime} \mathrm{W}\right)$ on the northem coast of Fuerteventura, one of the seven islands of the 
Canary archipelago. Fuerteventura is the island nearest to the northwestern Sahara and is located $100 \mathrm{~km}$ west of the African coast. The local mineral assemblage coming from its volcanic substratum (basalts and gabbros) is very different from that expected from the potential Saharan sources (mainly clay minerals, calcite, and quartz) and allows a good distinction between the local and remote contribution. Moreover, local pollution sources are very scarce on this island.

The samples were collected between July 18 and July 31,1985 , at the top of a $15-\mathrm{m}$-high building, by bulk filtration on $0.4-\mu \mathrm{m}-$ pore-size Nuclepore filters. The sampling duration ranged between 12 and 36 hours. A flow rate of about $1 \mathrm{~m}^{3} \mathrm{~h}^{-1}$ was used during the sampling period.

The samples were successively analyzed by $X$ ray fluorescence (XRF), $X$ ray diffraction (XRD), and by scanning electron microscopic analysis (SEM), coupled with an energy dispersive $X$ ray analyzer (EDS).

Elemental analyses ( $\mathrm{Al}, \mathrm{Si}, \mathrm{P}, \mathrm{S}, \mathrm{Cl}, \mathrm{K}, \mathrm{Ca}, \mathrm{Mn}, \mathrm{Fe}$, and $\mathrm{Zn}$ ) have been performed by wavelength dispersive $X$ ray fluorescence spectrometry (CGR $\alpha 10$ ), according to the method described by Losno et al., [1987], using an X ray tube with $\mathrm{Cr}$ or W targets. Analytical precision is better than $7 \%$ for every analyzed element except $\mathrm{Zn}(10 \%)$. Elemental concentrations are reported in Table 1.

Mineral components were identified directly on the filter by $\mathbf{X}$ ray diffraction (Philips Diffractometer PW 1130), using Fe filtered $\mathrm{Co} \mathrm{K} \alpha$. The $\mathrm{X}$ ray record of an unexposed filter shows a strong line between 4.50 and $5.70 \AA$ and reaches a maximum at $5.10 \AA$, this area was consequently unusable.

The gold-plated samples were examined by a Jeol JSM 2 SEM with energy dispersive system (EEDS Ortec). More detail about these analytical techniques is available in the work by CoudéGaussen et al. [1987].

\section{Meteorological Situation and Trajectory ANALYSIS}

The Canary Islands are located in an area particularly affected by the seasonal meridional shifts of the subtropical anticyclone [Huetz de Lemps, 1969]. Moreover, these islands are also on the path of cold polar air masses. For these reasons, the climatology during the intermediate seasons (spring and fall) is extremely variable, and previous work [Coudé-Gaussen et al., 1987] illustrates the complexity of the meteorological situations favorable to dust transport to the Canary Islands during spring. On the other hand, during summer the subtropical high moves northward: generally, the Canary Islands are dominated by its influence, and dry weather prevails. Hence the meteorological situation is very stable. It is also interesting to emphasize that the northem trade winds originate in this area.

Many studies have shown that air mass trajectories are a useful tool to describe dust transport at a synoptic scale [Reiffet al., 1986]. These trajectories, combined with geochemical or mineralogical tracers, have been used to determine the source regions of natural or anthropogenic particulate matter in various environments [Merrill, 1986; Bergametti, 1987; Colin et al., 1989].

Three-dimensional air mass trajectories have been computed by the Service des Etudes Spéciales de la Météorologie Nationale (France), using wind analysis processed 4 times a day by the European Centre for Medium-Range Weather Forcasting, (ECMWF) in Reading, England. The software [Imbard, 1983] allows the computation of trajectories for any starting or ending point at any time. The vertical level is specified for the initial point and the trajectories are computed, taking into account the vertical velocity

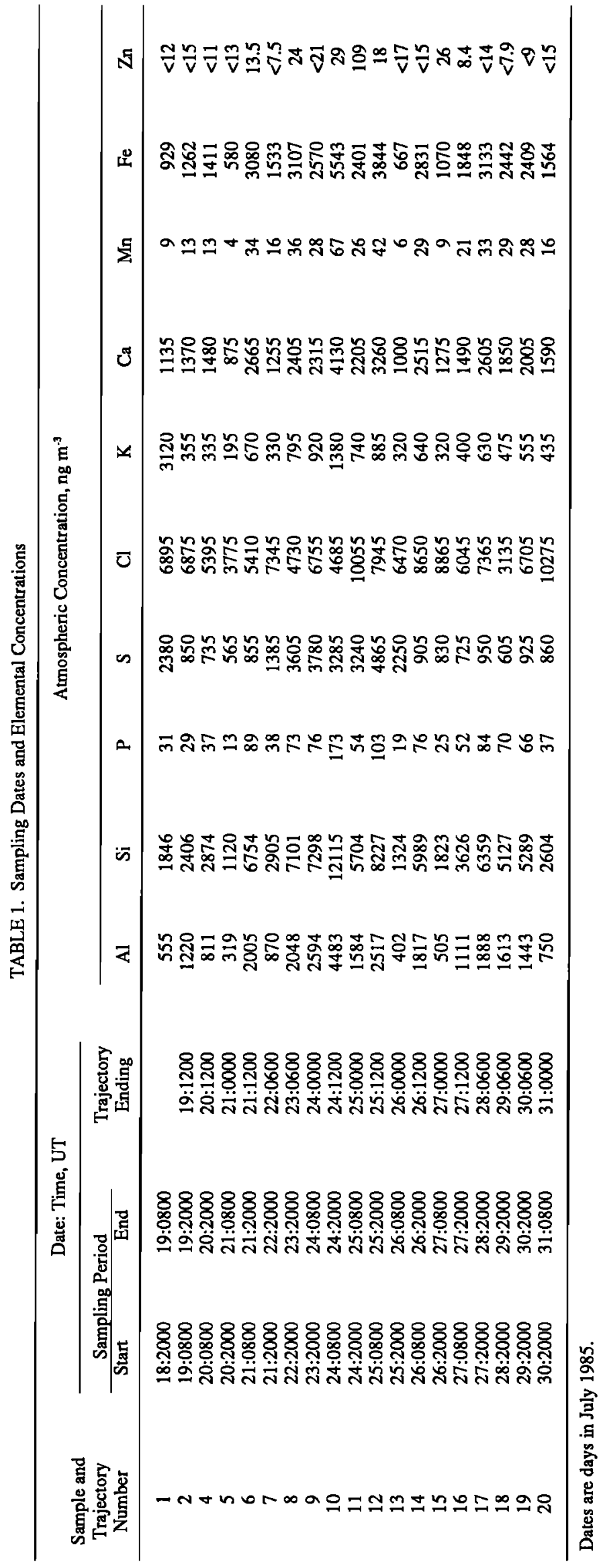


values in the archive. Martin et al. [1987] have pointed out that the vertical velocity is a necessary parameter to integrate in computed trajectories in order to reproduce the actual displacement of the air masses.

In this study, two backward trajectories, ending at the 925- and 850-hPa barometric levels, have been computed for the median time of each sample. The duration of each trajectory is 96 hours.

As a first step, trajectory analysis enables the separation of six distinctive periods during the sampling experiment (Figure 1):

1. From July 18 (2000 UT) to July 19 (2000 UT), the Canary Islands are subjected to northern oceanic influence in the lower atmospheric layers $(925 \mathrm{hPa})$ and are affected by African air masses at the upper barometric level $(850 \mathrm{hPa})$, shown by trajectory 2 in figure 1.

2. From July 19 (2000 UT) to July 21 (0000 UT), we observe an oceanic influence for the two barometric levels investigated (trajectories 4, 5 in figure1).

3. From July 21 (1200 UT) to July 25 (0000 UT), an oceanic circulation remains in the lower layer, while a new African influence is suggested by the trajectories ending at $850-\mathrm{hPa}$ (trajectories 6 to 11 in figure 1 ).

4. From July 25 (1200 UT) to July 27 (1200 UT), the Canary Islands are again subjected to continuous oceanic conditions (trajectories 12 to 16 in figure 1 ).
5. From July 28 (0600 UT) to July 29 (0600 UT), the oceanic influence is always present in the lower layer, but a new African contribution is obvious in view of the $850-\mathrm{hPa}$ trajectories (trajectories 17,18 in figure 1$)$.

6. From July 30 (0600 UT) to July 31 (0000 UT), only oceanic influences are indicated by air-mass trajectories (trajectories 19 , 20).

In summary, it is worthwhile to note that the trajectories ending at $925-\mathrm{hPa}$ indicate only oceanic influences during the whole sampling period. The advection of air masses from Africa is observed only in the 850-hPa trajectories.

The pure oceanic influences are easily characterized by an atmospheric circulation controlled by the Azores High. The July 21 (0000 UT) situation is given as an example of such conditions (Figure 2).

The advection of African air masses over the Canary Islands appears more complex and at least two different source regions can be deduced from trajectories: a northern source from Morocco and another one from more southern desert areas (Figure 1). It is obvious that these two different origins for the observed dust result from different circulation pattems controlled by the several active centers.

A first indication of the meteorological processes involved in the transport of African air masses to the Canary Islands is provided by
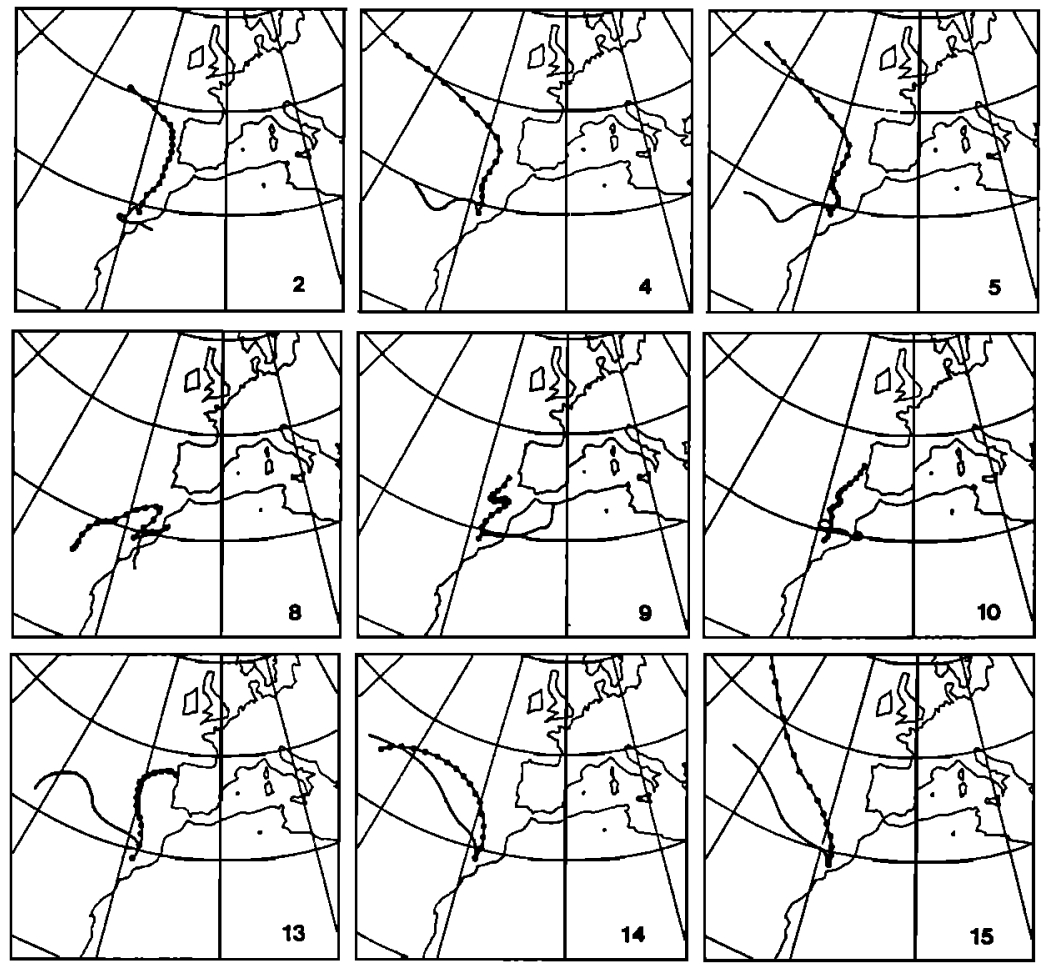

10
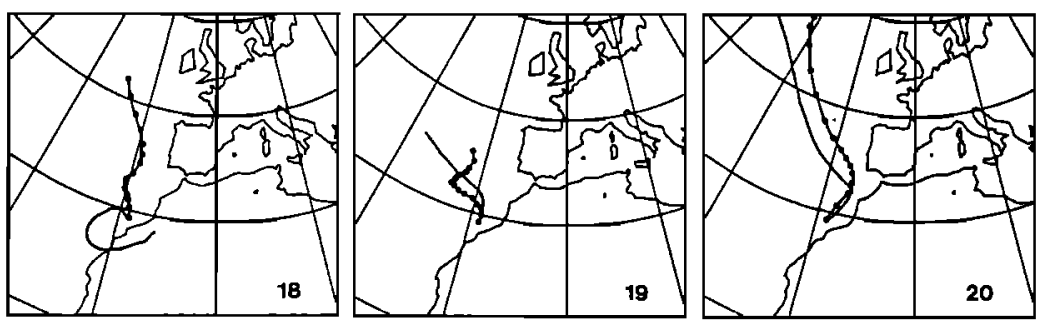
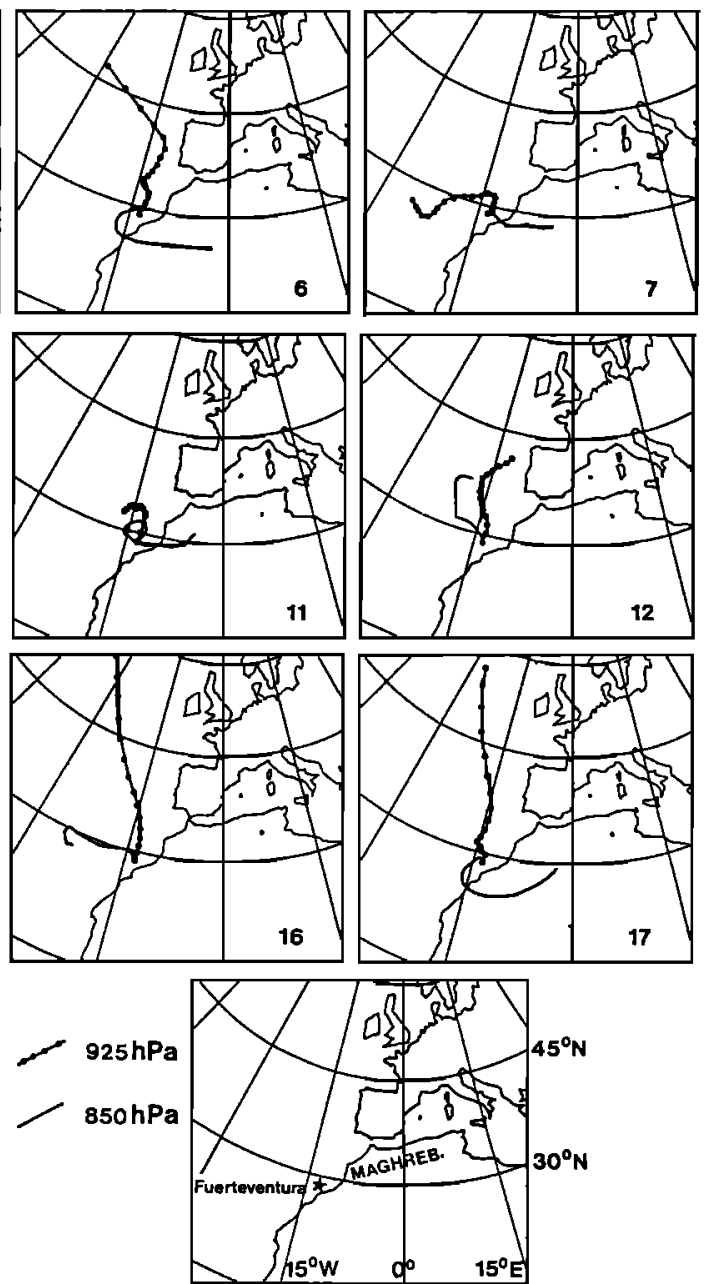

Fig. 1. Air-mass trajectories terminating over Fuerteventura for two barometric levels: $925 \mathrm{hPa}$ (dotted-line curve), an $850 \mathrm{hPa}$ (smooth line curve) during the whole sampling period (the numbers refer to dates reported in Table 1). 


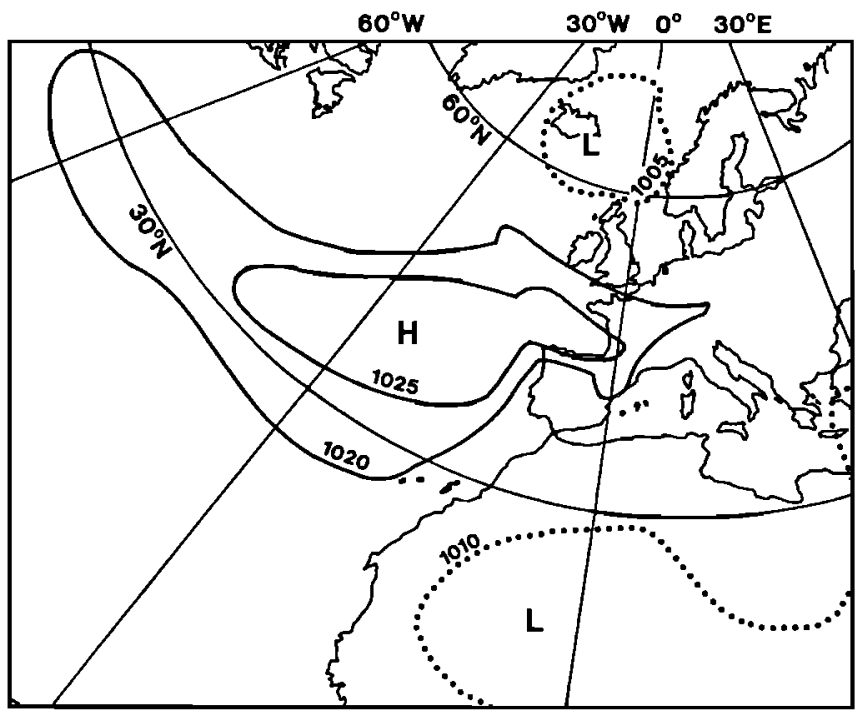

Fig. 2. Meteorological situation for oceanic influence over Canary Islands during the sampling period (July 21, 1985; OOOO UT; surface chart).

studying the vertical motion of the relevant trajectories at the synoptic scale. Figure 3 shows these vertical movements for the trajectories, indicating transport cases from Africa at $850-\mathrm{hPa}$. We observe that a systematic downward movement is associated with these trajectories. The mean barometric level of the air masses when they moved over the potential source regions lies between 700 - and $850-\mathrm{hPa}$, depending on the case. So we focus our attention on the meteorological maps for these levels.

On these maps we have compared the situations corresponding to the cases of dust transport from either Morocco or southern source regions (Figure 4). From these maps we note that the airflows are in the two cases controlled by a high-pressure cell located over Western Europe or Northern Africa, respectively. It is probable that the differences in dust source area can be attributed to fluctuations in the position of the high-pressure center. For example, from July 21 to July 24, 1985, the air mass coming from Africa, remains at 850-hPa. At this level, the subtropical anticyclone extends between the Azores and Westem Europe, which is its average position for the summer season.

Consequently, such a situation generates a northeastern flow at 850-hPa over northwestem Africa and Fuerteventura, and hence it is likely that the dust observed on July 24,1985 over the Canary Islands originated from the Atlas chain.

From July 24,1985 , the extended subtropical anticyclone moved southward, while the air masses, originating from Africa, were transported at 700-hPa. This anticyclonic motion results from the incursion of a polar air mass over the eastern Atlantic. Hence the African air mass transport is controlled by an eastern flow coming from more southern regions of North Africa. Moreover, on July 26, 1985, the polar air mass low cuts the anticyclonic wedge, which generates a closed high-pressure center over North Africa. Consequently, from this date the wind flow is diverted northward, which is well visible on the trajectory ending at $850-\mathrm{hPa}$ on July, 28, 1985, at Fuerteventura (trajectory 17 in figure 1).

In this brief meteorological study of airflow patterns over the Canary Islands during this summer period, it has been pointed out that the high-pressure cells control the atmospheric circulation in this region. The respective positions of both the principal Azores center and its secondary branches (over southem Europe or North Africa) impose either global north to northwestern atmospheric circulation (at 925 - and $850-\mathrm{hPa}$ levels) or a split circulation

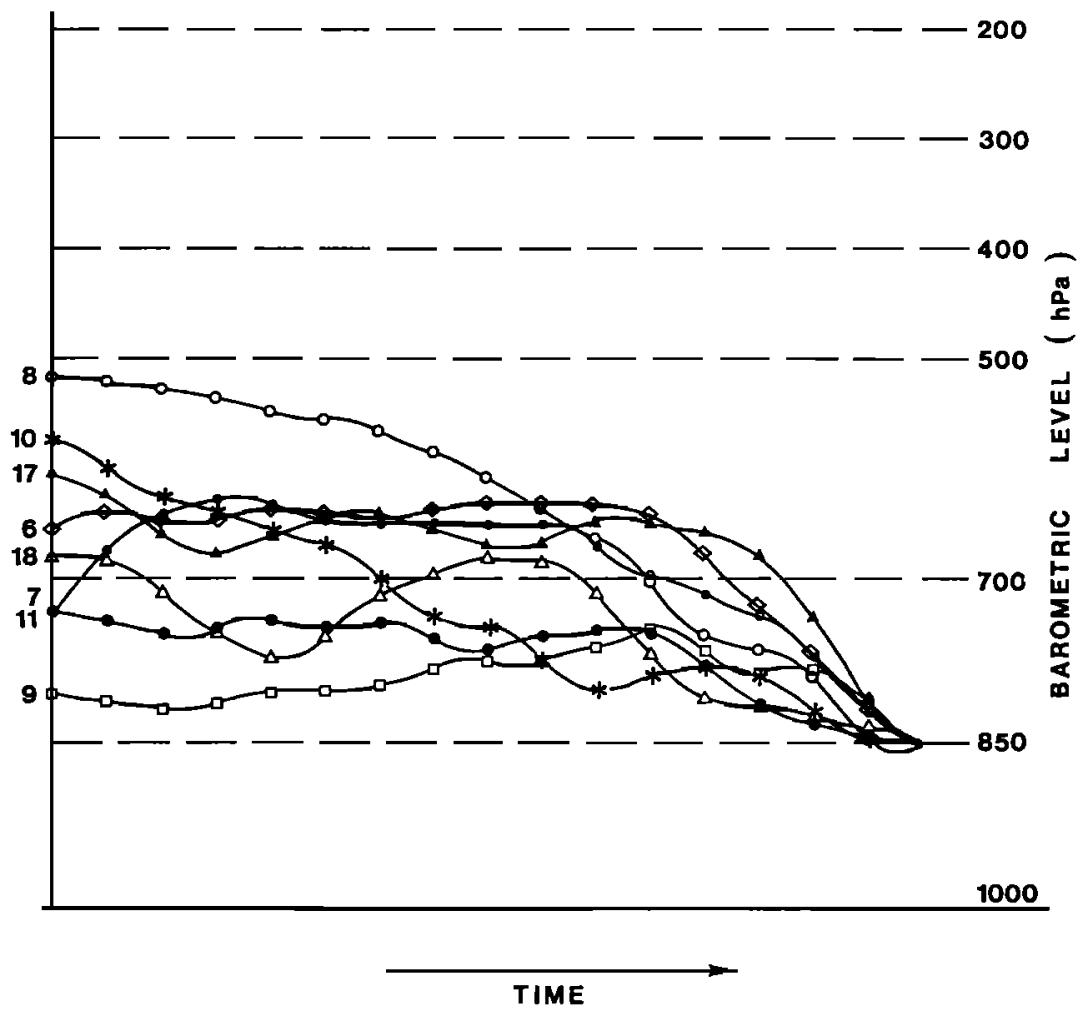

Fig. 3. Vertical movements during 4 days at a synoptic scale of an air mass originating from African regions and sampling over Fuerteventura (the sample numbers are reported on each vertical motion; the interval between two symbols corresponds to 6 hours). 


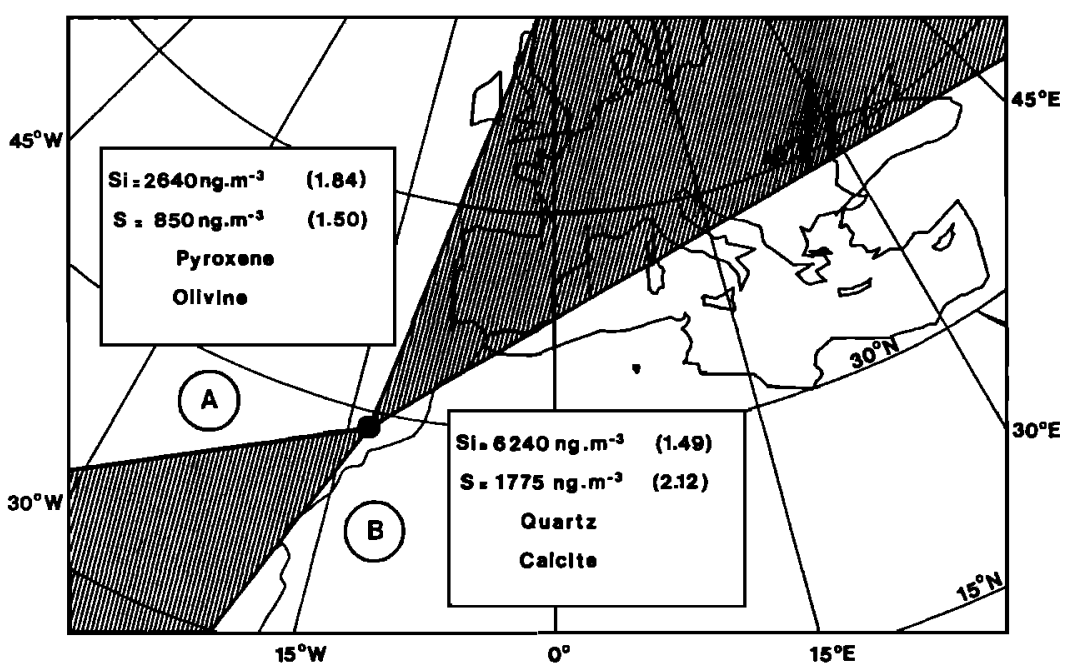

Fig. 4. Silicon and sulfur average concentrations, geometric standard deviations and mineral compounds observed during oceanic (area A) and continental (area B) cases of transport.

(oceanic and continental) at each barometric level. Moreover, the meridional fluctuations of the continental high-pressure cells generate airflows from northern or more southern African origins.

\section{Chemical and Mineralogical Composition of the Particulate Matter}

In order to investigate changes in particulate atmospheric matter in relation to air mass trajectories, different sectors of origin have been drawn. These sectors have been defined from $850-\mathrm{hPa}$ trajectories which exhibit successively continental or oceanic influences. However, three samples have been eliminated: sample 1, for which the air mass trajectory at $850-\mathrm{hPa}$ is not available; sample 2 , for which the wind speed is particularly low and consequently the confidence in the air mass trajectory is limited; sample 3, which was not collected; and sample 12, which was also rejected because the relevant trajectory corresponds to an intermediate situation with a mixed origin of dust: in this case, one can consider that this sample is not purely representative of a typical kind of source region.

First, we will try to distinguish between continental and oceanic origins. From our samples we can define the two sectors reported on Figure 4: one corresponding to Atlantic air masses and the other one including the cases of transport from African regions. Transport from the south-west and from Europe does not occur during this field experiment.

Silicon, which can be considered as a tracer of the terrigeneous contribution, and sulfur, which mainly results from anthropogenic activities, were selected to characterize the composition of these air masses in each sector. We can observe that both $\mathrm{Si}$ and $\mathrm{S}$ concentrations are significantly lower for samples associated with oceanic air mass trajectories than in the case of transport from the African continent. This agrees with the absence of important sources, either terrestrial or industrial, during Atlantic transport. Indeed, sulfur concentrations are rather comparable with those observed at these latitudes over marine regions [Bonsang, 1980; Delmas and Servant, 1982] and are also in accordance with those observed (unpublished results) during the previous study on Fuerteventura [Coudé-Gaussen et al., 1987]. On the other hand, silicon concentrations are relatively high compared to those generally found over Atlantic Ocean without dust transport [Duce et al., 1975; Buat-Ménard and Chesselet, 1979]. This is probably due to a significant local contribution, which is particularly evident considering SEM exa- mination showing autochtoneous particles such as pyroxene, olivine, and sphene. The occurence of olivine is an interesting indicator of probable influence from Lanzarote Island (located about $20 \mathrm{~km}$ North of Corralejo), where this mineral is known to be abundant. This local contribution of soil particles is more important than that observed in April 1984 by Coude-Gaussen et al. [1987]. This difference probably results both from more drier weather conditions and/or from an increase in local wind speed.

Obviously, Si concentrations are more than 2 times higher and both $\mathrm{X}$ ray diffraction and SEM examination show the presence of quartz and calcite when trajectories indicate transports from African regions. This should be related to a more intensive emission of soil-derived particles from the arid and semiarid regions of Africa.

In the same way, SEM and EDS examinations have been performed on the samples. According to their micromorphological features and mineralogical identification, the particles examined have been classified in terms of origins. Thus it is possible to distinguish particles very probably resulting from (1) anthropogenic emissions (Al or Ba microballs, Au or talc particles, flyingashes); (2) marine source (mainly chlorides, etc.); (3) local terrestrial sources according to the volcanic substratum of the Canary Islands (pyroxenes/amphiboles, olivines, magnetites, volcanic glasses, etc.); (4) allogeneous terrestrial sources, showing the typical micromorphology and mineralogy of Saharan dust particles (quartz, rounded $\mathrm{Ca}$ carbonate or dolomite, wind-shaped palygorskite grains, rounded feldspars and kaolinite particles, etc.). On the other hand, many particles are less easily classified but often have some micromorphological or mineralogical characters that show a possible marine (gypsum, $\mathrm{KCl}$, etc.) or allogeneous origin (clayed mixings, phyllites, etc.). In the samples examined by SEM, the percentages of each kind of particle have been counted, and they generally confirm the low contribution of the local material, as is well shown by these two cases (Table 2).

Sulfur concentrations also increase for samples associated with continental air masses, but we must emphasize that a significant dispersion of the values occurs for this element, as shown by its larger standard deviation (Figure 4).

Consequently, it is necessary to investigate more precisely the possible source regions of both dust and anthropogenic particles during cases of transport from the African regions. However, since $\mathrm{Si}$ and $\mathrm{S}$ come from different types of sources (crustal and mainly 
TABLE 2. Origins of Mineral Compounds Observed on Samples 1 and 10.

\begin{tabular}{lcc}
\hline \multirow{2}{*}{\multicolumn{1}{c}{ Origin }} & \multicolumn{2}{c}{ Sample } \\
\cline { 2 - 3 } \multicolumn{1}{c}{} & 1 & 10 \\
\hline Anthropogenic contribution & $15 \%$ & $4 \%$ \\
Marine source & $18 \%$ & $\ldots$ \\
Possible marine source & $15 \%$ & $24 \%$ \\
Local source & $8 \%$ & $22 \%$ \\
Allochtonous source & $16 \%$ & $26 \%$ \\
Possible allochtonous source & $27 \%$ & $24 \%$ \\
\hline
\end{tabular}

anthropogenic, respectively), we have to define different sectors for each element.

As shown in Figure 5, sulfur concentrations change significantly when we consider transport from northern Morocco $\left(3470 \mathrm{ng} \mathrm{m}^{-3}\right)$ or from more southern African countries $\left(908 \mathrm{ng} \mathrm{m}^{-3}\right)$. This pattern is in agreement with the location of industrial activities in this region: the anthropogenic emission strength is significantly higher in northern Morocco, where the major cities and plants are located. In contrast, southern Morocco and the Sahelian countries are scarcely industrialized and are sparsely settled. According to these data, it is probable that the highest pollution levels observed over Fuerteventura originate from northem Morocco, at least during summer.

\section{Source Regions of African Dusts}

\section{Meteorological Approach}

Information on possible source regions of dust observed over Fuerteventura can be obtained by various other methods:

1. On the European Meteorological Bulletin (EMB), dust storms are reported when they are observed at a meteorological station. Moreover, strong atmospheric dust contents are also indicated.

2. Nephanalysis (NA), performed from the Meteosat satellite(Centre de Météorologie Spatiale, Lannion, France) enables the determination of the dust cloud extent over the African continent.

3. Satellite imagery (from Meteosat or NOAA 9) from the visible channel (over the sea) or infrared channel (over the continent) is useful in reconstructing dust pathways from their emission up to the extinction of the signal; this occurs at different distances from the sources as a function of the intensity and dispersion or scavenging of dust.

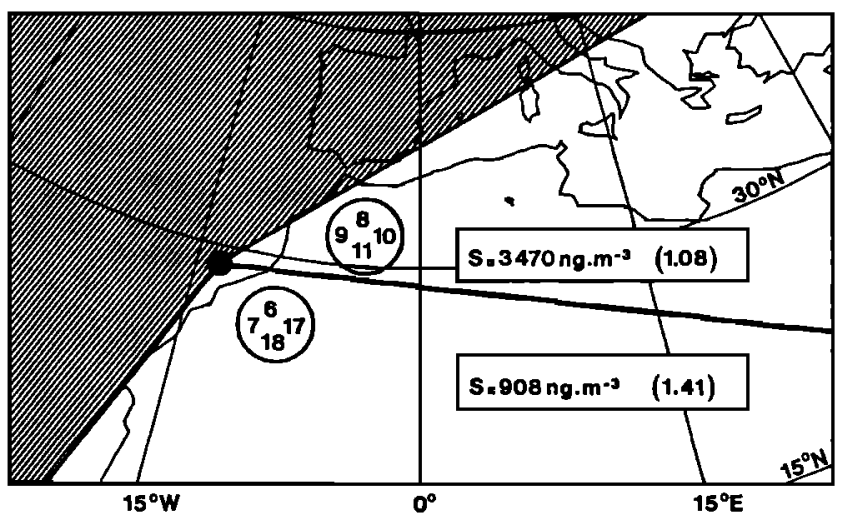

Fig. 5. Average concentrations of particulate sulfur and geometric standard deviations for the two continental source regions.
Obviously, air mass trajectories also contribute to the global interpretation of the information deduced from the previous techniques. Using these tools, three different periods can be distinguished for the dust transport cases from African regions to Canary Islands during our sampling campaign:

1. On July 16, EMB indicates a duststorm originating on the loop of Niger (Gao meteorological station, Mali). In this region the surface circulation is controlled by a small trough (located over Taoudeni Basin), which generates a south-southwestem flow. The dust cloud is clearly visible on the Meteosat image (July 16, 1985, $1200 \mathrm{UT}$ ), which shows that the dust extended up to $25^{\circ} \mathrm{N}$ (Figure 6a).
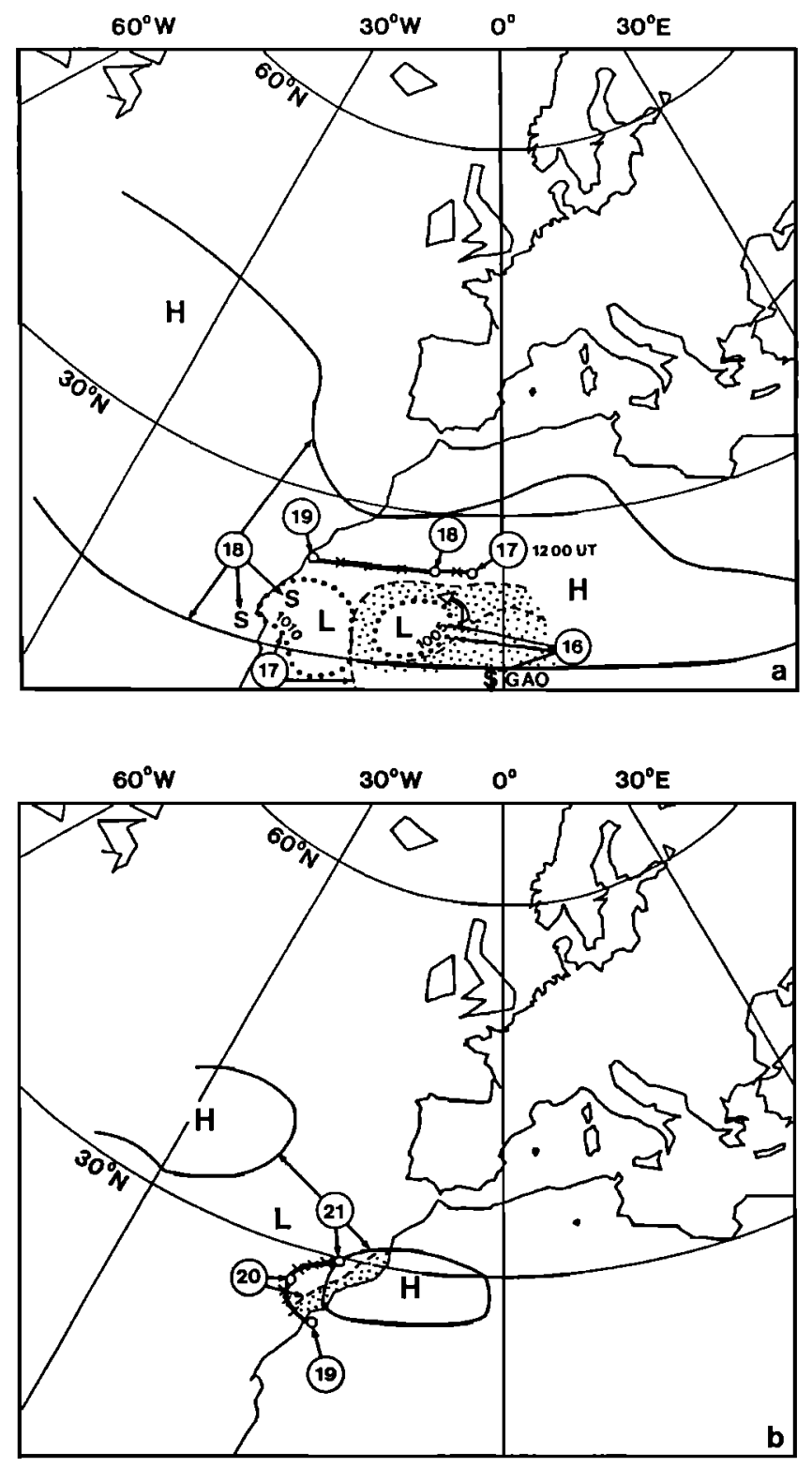

Fig. 6. Atmospheric pathway of the dust cloud from its rising area (Gao region, Republic of Mali) on July 16,1985, to Fuerteventura Island on July, 21,1985 . Circled number indicate the date when the phenomenon is observed; the letter $S$ indicates dust rise high dust content in the atmosphere; the letter $S$ with a vertical line indicates dust rise; dots with a dashed margin indicate the boundaries of the dust cloud as observed from satellites images; arrows indicate movement of the dust; dotted margin around the letter $L$ indicates low pressure at ground level; solid lines around the letter $\mathrm{H}$ indicate high pressure at $850 \mathrm{hPa}$; solid curves with crosses indicate three-dimensional air mass trajectory ending on Fuerteventura at $850 \mathrm{hPa}$. 


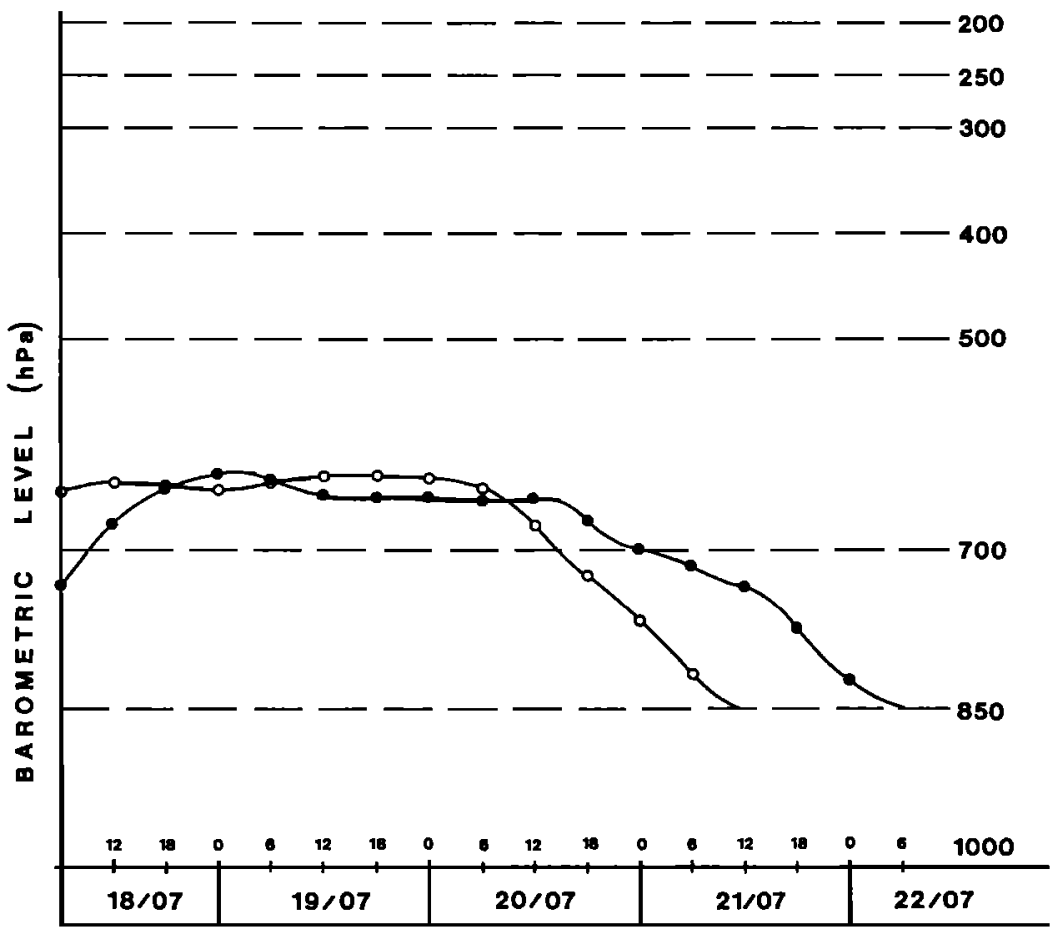

Fig. 7. Vertical movements of African air masses reaching the Canary Islands on July 21 and 22, 1985 (curves with open circles indicate July 21; curves with solid circles indicate July 22).

On July 17, at 1200 UT, Meteosat and NOAA images showed that the dust cloud had moved westward from $5^{\circ}$ to $10^{\circ} \mathrm{W}$ (Figure 6a).

On July 18 the dust cloud moves northward (Meteosat image). At this point, air mass trajectories arriving on Fuerteventura on July 21 and 22 are compatible with the transport of this dust cloud from the African continent to the Canary Islands (Figure 6b). These trajectories are typical of an anticyclonic circulation, which is generated by the high-pressure cell located over Maghreb. It is worthwhile to note that these trajectories indicate that the transport of this dust over the African continent occurs at the $600-\mathrm{hPa}$ barometric level until it reaches the Atlantic shoreline when an abrupt downward movement is observed (Figure 7).

2. On July 24, at 1228 UT, the NOAA 9 satellite shows a dust cloud, which extended over the Canary Islands. An air mass trajectory arriving over Fuerteventura on July 24 (0000 UT) indicates a transport of the order of 2 or 3 days from northeastern Moroccan regions. Between these Moroccan regions and the Canary Islands, a northeastern flow is established and controlled by a high-pressure cell located on Spain and the western Mediterranean sea. EMB mentions an anomalous high dust concentration over the Tafilelt on July 21 . Hence it is probable that the dusts observed over Fuerteventura on July 24, at 0000 and 1200 UT originated from northeastern Morocco (Figure 8).

3. The dust observed over Fuerteventura on July 28 and 29 results from an atmospheric pathway and source region similar to those described for July 16-18 (Figure 9).

On July 24, EMB indicates a duststorm originating in the Gao region. This dust was loaded in a south-southwestern flow, resulting from a trough located over the Tanezruft Plain (Figure 9a).

On July 25, EMB indicates a high dust content in the atmosphere over the western Hoggar. The same day, NOAA 9 shows an extension of this dust cloud northward (Figure 9a). Air mass trajectories arriving over Fuerteventura on July 28 (0600 UT) and 29 (0600 UT) show that the western part of this dust cloud was transported to the Canary Islands by an anticyclonic southwestern

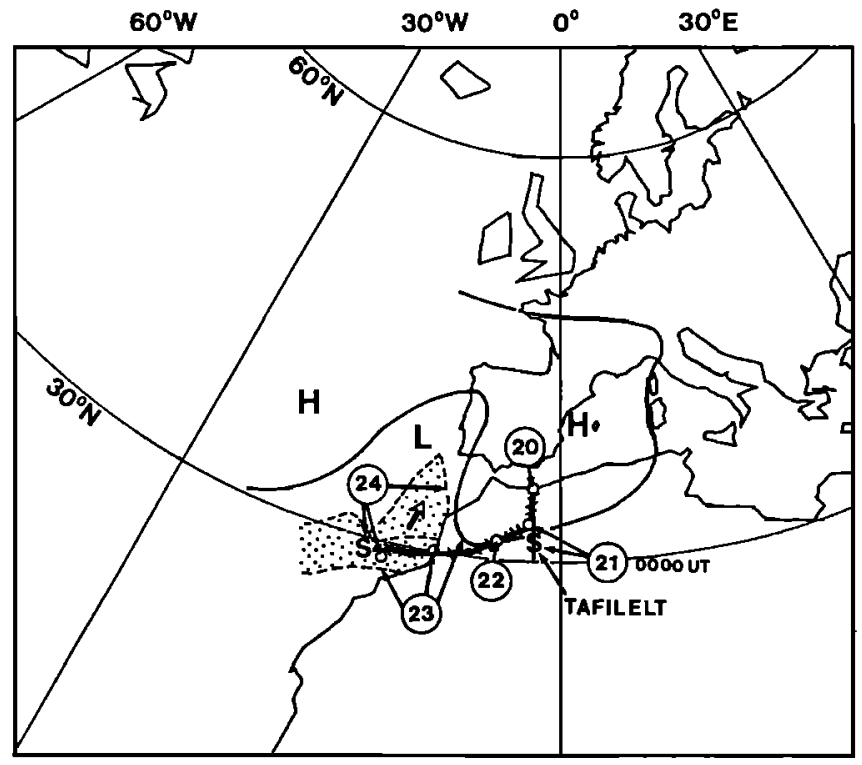

Fig. 8. Atmospheric pathway of the dust cloud from its rising area (Tafilelt, Morocco) on July, 21, 1985 to Fuerteventura Island on July 24, 1985 (symbols are the same as for Figure 6).

flow resulting from the high-pressure cell located over the Sahara (Figure 9c).

We can conclude that dust transports from African regions to the Canary Islands seem to be possible only when the Azores High is separated in two distinctive cells, one located over the Atlantic Ocean and the other over Africa. This division results mainly from the incursion of a polar air mass over the eastern Atlantic. The African cell allows the dust to move northward along the discontinuity (Figure 10). 

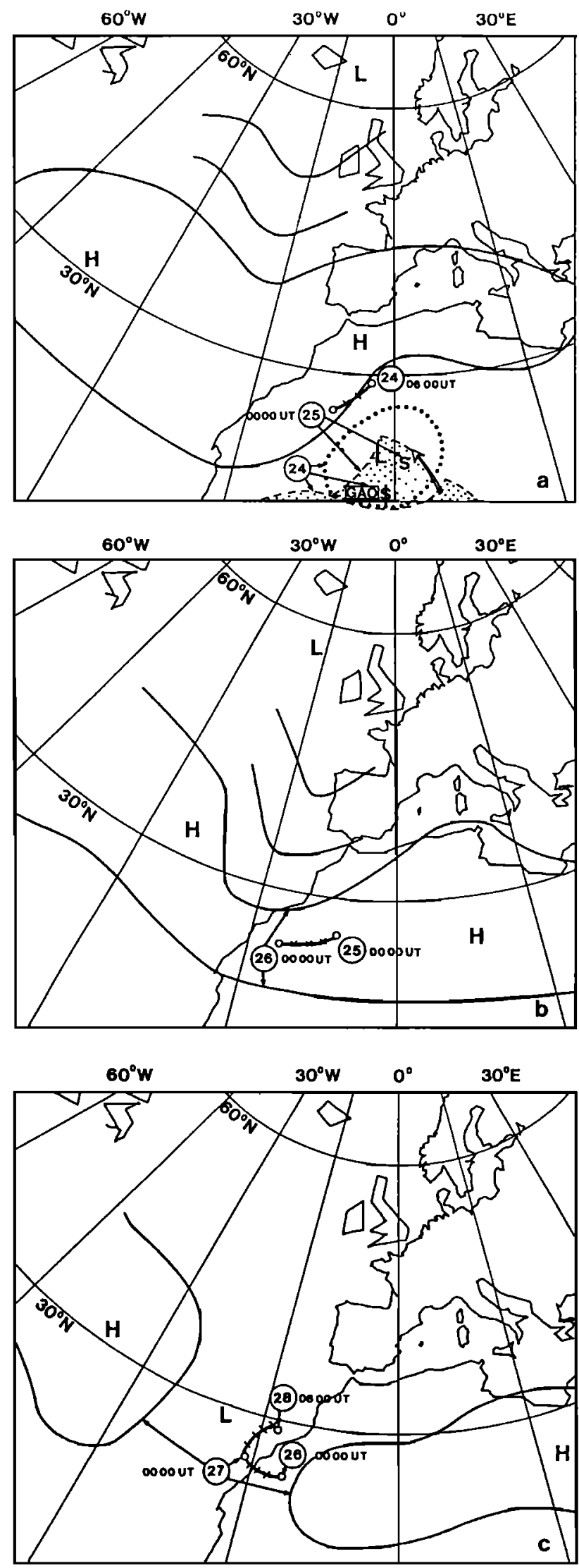

Fig. 9. Atmospheric pathway of the dust cloud from its nsing area (Gao region, Republic of Mali) on July 24, 1985, to Fuerteventura Isl and on July 28 , 1985 (symbols are the same as for Figure 6).

\section{Geochemical and Mineralogical Approach}

This meteorological analysis of source regions and transport processes of African dust over Fuerteventura enables the distinction of two different origins: a Sahelian origin for dust arriving on July 21-22 and 28-29 and a Moroccan Atlas origin for the dusts arriving on July 24.

Now we will compare chemical abundance and mineral composition of desert dusts for each source region. Figure 11 reports the $\mathrm{Si} / \mathrm{Al}$ and $\mathrm{Fe} / \mathrm{Al}$ ratios of dusts for each case. Note that both $\mathrm{Si} / \mathrm{Al}$ and $\mathrm{Fe} / \mathrm{Al}$ ratios increase strongly for dusts associated with a Sahelian source compared to a Moroccan one. These results can be compared with those obtained on Corsica Island by Bergametti et al. [1989]. These authors investigated six cases of dust transport from northem Morocco and they noticed a $\mathrm{Si} / \mathrm{Al}$ ratio equal to 2.67 , which is very close to our values of 2.70 and 2.87 , whereas a slight difference exists between our $\mathrm{Fe} / \mathrm{Al}$ ratio (1.1) and theirs (0.67). In the same way, these authors documented a case originating from a Sahelian source similar to ours and they found $\mathrm{Si} / \mathrm{Al}$ ratios (3.353.61) and $\mathrm{Fe} / \mathrm{Al}$ ratios (1.53-1.69) very close to those that we observe for the dust originating from these regions (Si/Al: 3.183.60; Fe/Al: 1.51-1.76).

The difference in composition of dust from these two source regions must be interpreted in relation to the nature of the respective soils. The increase of $\mathrm{Si} / \mathrm{Al}$ ratios for dust of southern regions probably reflects the more sandy character of the Sahelian regions compared to the Atlas mountains. The increase of $\mathrm{Fe} / \mathrm{Al}$ ratios probably results from changes in clay minerals. The Sahelian regions are known to present abundant ferrallitic soils [Millot, 1964; Sys, 1967]. SEM and EDS examinations confirm these assumptions: dust originating from Sahelian regions shows numerous clay minerals in which iron is a dominant element, while iron only appears as a minor component in clay minerals present in dust originating from northern Morocco.

\section{CONCLUSIONS}

This study suggests that two different African source regions are involved in the transport of desert dust to the Canary Islands and the Northem Atlantic in summer. Transport from the Sahelian regions is observed when a wedge resulting from a southern incursion of the polar depression cuts the Azores High into two anticyclonic cells, an oceanic and a continental one, the continental anticyclonic cell being located on the Maghreb.

On the other hand, northeastem Morocco is the main source region of dust affecting the Canary Islands when the Azores High is in its average summer position, that is, when it extends from the western Atlantic up to Western Europe. In contrast to the previous work by Coudé-Gaussen et al. [1987] who documented dust transport over the Canary Islands during an intermediate season (spring 1984), the source region of dust in summer is rather different. Coudé-Gaussen et al. have shown that only northem and southern Moroccan areas emitted dust that is transported to the Canary Islands. Allowing for the limited duration of each campaign and their low representativeness from a climatological point of view, it seems that the Sahelian regions mainly contribute to the dust content in this area during summer, while our data suggest that the Canary Islands can be submitted to dust transport from Moroccan sources whatever the season.

Another important feature is that the summer cases of dust transport are always characterized by anticyclonic trajectories, allowing a direct transfer from source regions to Canary Islands. On the other hand, during spring, Coudé-Gaussen et al. [1987] have 


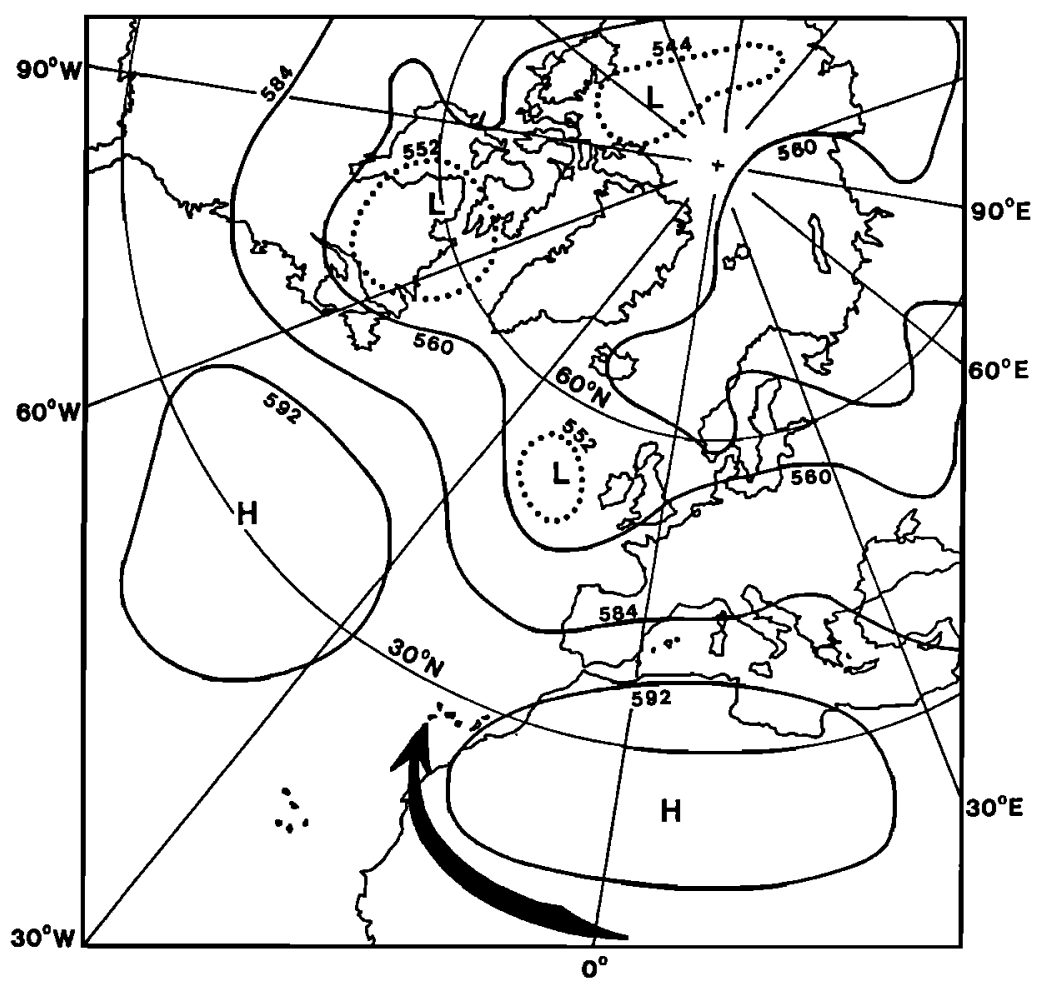

Fig. 10. Typical meteorological situation for dust transport over the Canary Islands in an anticyclonic flow (July 28, 1985; 0000 UT; $500 \mathrm{hPa}$ ). The arrow indicates the direction of the dust transport.

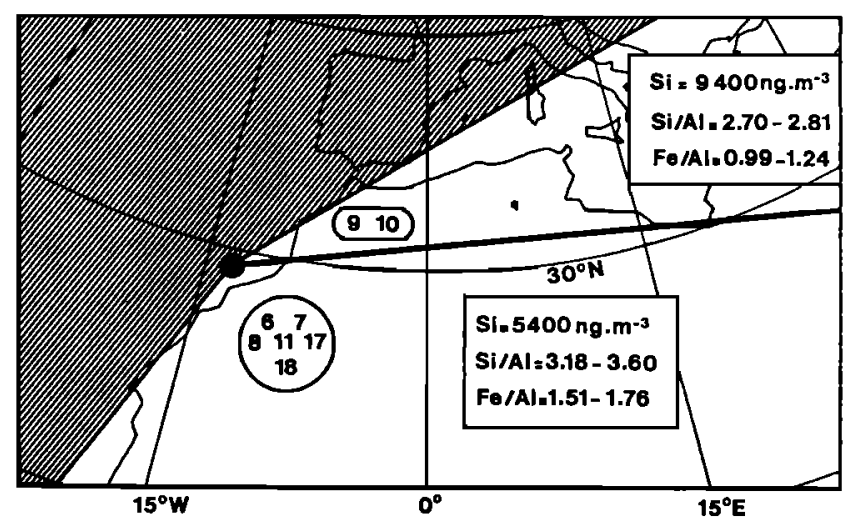

Fig. 11. Si/Al and $\mathrm{Fe} / \mathrm{Al}$ ratios for dust associated with air masses coming from northem and southern African source regions.

largely documented a dust outbreak from Morocco transported in a cyclonic flow, which has lead to an indirect transport of dust: a 6 day voyage over the North Atlantic is observed before the dust reaches the Canary Islands.

It is obvious that long time series of measurements are necessary to clearly point out the major dust transport patterns in this marine region. However, the work performed by Oliva et al. [1983] provides a useful statistical basis to approach the dust transport over this area. These authors, by using satellite imagery over a 1-year period (1979), have shown that the frequency of dust export beyond the Moroccan shorelines is maximal during the warm period (MayAugust). So it can be proposed that the Sahelian sources of dust, even though they are a relatively large distance from the Canary Islands, could be a significant contributor to aeolian transport in this region.
Another conclusion in this study is the confirmation of the usefulness of elemental ratios such as $\mathrm{Si} / \mathrm{Al}$ and $\mathrm{Fe} / \mathrm{Al}$ in connection with air mass trajectories in distinguishing various source regions of dust. The signatures observed for Sahelian or Moroccan sources are both in good agreement with the previous observations performed in the western Mediterranean when African dust incursions occurred. Although further investigations are needed, it seems that the variations of these ratios can be related to changes in clay mineral composition and/or in quartz content.

Acknowledgments. We wish to thank the Spanish authorities and especially Gerardo Mesa, Cabildo of Fuerteventura, for their full support. We would like to mention the friendly cooperation of the Centre de Météorologie Spatiale (CMS) of Lannion, France; B. Strauss and J.M. Gros, Service des Etudes Spéciales de la Météorologie Nationale, Paris, who computed the air mass trajectories, and J. Davies for critical comments. We also thank B. Chatenet for technical support and especially for illustration. This work was supported by the French Centre National de la Recherche Scientifique.

\section{REFERENCES}

Bach, W., Global air pollution and climatic change, Rev. Geophys., 14, 429-474, 1976.

Bergarnetti, G., Apports de matière par voie atmosphérique à la Méditerranée Occidentale: aspects géochimiques et météorologiques, Thèse d'Etat, 299 pp., Université Paris VII, 1987.

Bergametti, G., L. Gomes, E. Remoudaki, M. Desbois, D. Martin, and P. BuatMénard, Present transport and deposition pattems of African dusts to the Northwestem Mediterranean, in Paleoclimatology and Paleometeorology: Modern and Past Patterns of Global Atmospheric Transports, edited by M. Leinen and M. Samthein, D. Reidel, Hingham, Mass.,in press, 1989. Bonsang, B., Cycle atmosphérique du soufre d'origine marine, Thèse d'Etat, 222 pp, Université de Picardie, 1980. 
Buat-Ménard, P., and R. Chesselet, Variable influence of the atmospheric fluxes on the trace metal chemistry of oceanic suspended matter, Earth Planet. Sci. Lett., 42, 399-411, 1979.

Carlson, T. N., and J. M. Prospero, The large-scale movement of Saharan air outbreaks over the northem equatorial Atlantic, J. Appl. Meteorol., 11, 283-297, 1972.

Chester, R., The marine mineral aerosol, in The Role of Air-Sea Exchange in Geochemical Cycling, edited by P. Buat-Ménard, pp. 443-471, D. Reidel, Hingham, Mass., 1986.

Chester, R., A. G. Griffiths, and J. M. Hirst, The influence of soil-sized atmospheric particulates on the elemental chemistry of the deep-sea sediments of the North Eastem Atlantic, Mar. Geol., 32, 141-154, 1979.

Chester, R., E. J. Sharples, G. S. Sanders, and A. C. Saydam, Saharan dust incursion over the Tyrthenian Sea, Atmos. Environ., 18, 929-935, 1984.

Colin, J. L., D. Renard, V. Lescoat, J. L. Jaffrezo, J. M. Gros, and B. Strauss, Relationships between rain and snow acidity and air mass trajectories in eastem France, Atmos. Environ., 23, 1487-1498, 1989.

Coudé-Gaussen, G., P. Rognon, G. Bergametti, L. Gomes, B. Strauss, J. M. Gros, and M. N. Le Coustumer, Saharan dust on Fuerteventura Island Chemical and mineralogical characteristics, air mass trajectories, and probable sources, J. Geophys. Res., 92, 9753-9771, 1987.

Delany, A. C., D. W. Parkin, J. J. Griffin, E. D. Goldberg, and B. E. Reimann, Airbome dust collected off the West African coast, Geochim. Cosmochim. Acta, 31, 885-909, 1967.

Delmas, R., and J. Servant, The origins of sulfur compounds in the atmosphere of a zone of high productivity (Gulf of Guinea), J. Geophys. Res. $87,11,019-11,026,1982$.

Duce, R. A., G. L. Hoffman, and W. H. Zoller, Atmospheric trace metals at remote northem and southem hemisphere sites: pollution or natural?, Science, 187, 59-61, 1975.

Huetz de Lemps, A., Le climat des îles Canaries, 226 pp., Sedes, Paris, 1969.

Imbard, M., Trajectoires: Transport à longue distance, Note CETI, Mértérol Nat., Paris, 1983.

Losno, R., G. Bergametti, and G. Mouvier, Determination of optimal conditions for atmospheric aerosols analyses by $\mathrm{X}$ Ray fluorescence, Environ. Technol. Lett., 8, 77-87, 1987.

Löye-Pilot, M. D., J. M. Martin, and J. Morelli, Influence of Saharan dust on the rain acidity and atmospheric input to the Mediterranean, Nature, 321 . 427-428, 1986.

Martin, D., C. Mithieux, and B. Strauss, On the use of the synoptic vertical wind component in a transport trajectory model, Atmos. Environ., 21, 1115-1123, 1987.

Merrill, J. T., Atmospheric pathways to the oceans, in The Role of Air-Sea Exchange in Geochemical Cycling, edited by P. Buat-Ménard, pp 35-64, D. Reidel, Hingham, Mass., 1986.

Millot, G., Géologie des Argiles, 499 pp, G. Masson \& Cie, Paris, 1964

Oliva, P., G. Coudé-Gaussen, H. Delannoy, L. Dorize, P. Rognon, and M. Tabeaud, Etude de la dynamique de quelques lithométéores sahariens par télédétection spatiale, Méditerranée, 3, 21-52, 1983.
Prodi, F., and G. Fea, A case of transport and deposition of saharan dust over the Italian peninsula and southem Europe, J. Geophys. Res., 84, 6951$6960,1979$.

Prospero, J. M., Eolian transport to the world ocean, in The Oceanic Lithosphere, vol 7, The Sea, edited by C. Emiliani, John Wiley, New York, 1981.

Prospero, J. M., and T. N. Carlson, Vertical and areal distribution of Saharan dust over the western equatorial North Atlantic ocean,J.Geophys. Res., 77, 5255-5265, 1972.

Rea, D. K., and T. R., Janecek, Late Cenozoic changes in atmospheric circulation deduced from North Pacific eolian sediments, Mar. Geol., 49, 149-167, 1982.

Rea, D. K., M. Leinen, and T. Janecek, A geological approach to the long-term history of atmospheric circulation, Science, 227, 721-725, 1985.

Reiff, J., G. S. Forbes, F. T. M. Spieksma, and J. J. Reynders, African dust reaching northwestern Europe: A case of study to verify trajectory calculations, J. Clim. Appl. Meteorol., 25, 1543-1567, 1986.

Samthein, M., J. Thiede, U. Pflaumann, H. Erlenkeuser, D. Fütterer, B. Koopmann, H. Lange, and E. Seibold, Atmospheric and oceanic pattems off northwest Africa during the past 25 million years, in Geology of the Northwest African Continental Margin, edited by U. Von Rad, K. Linz, M. Samthein, and E. Seibold, pp. 545-604, Springer-Verlag, Berlin, 1982.

Savoie, D., and Prospero, J.M., Aerosol concentration statistics for the tropical north Atlantic, J. Geophys. Res., 82, 5954-5963, 1977.

Schütz, L., Long-range transport of desert dust with special emphasis on the Sahara, Ann. N. Y. Acad. Sci., 338, 515-532, 1980.

Schütz, L., and M. Kramer, Rain water composition over nural area with special emphasis on the size distribution of insoluble particulate matter, J. Atmos. Chem., 5, 173-184, 1987.

Sys, C., The concept of ferrallitic and fersiallitic soils in Central Africa, Pedologie, 17, 284-325, 1967.

Tsoar, H., and K. Pye, Dust transport and the question of desert loess formation, Sedimenology, 34, 139-153, 1987.

Uematsu, M., R. A. Duce, S. Nakaya, and S. Tsunogaï, Short-term temporal variability of eolian particles in surface waters of the northwestem North Pacific, J. Geophys. Res., 90, 1167-1172, 1985.

G. Bergametti and L. Gomes, Laboratoire de Physico-Chimie de l'Atmosphère, Université Paris 7, 2 place Jussieu, 75251 Paris cedex O5, France. G. Coudé-Gaussen and P. Rognon, URA CNRS 722, Centre National de la Recherche Scientifique, Université Pierre et Marie Curie, 4 place Jussieu, 75252 Paris cedex 05, France.

M. N. Le Coustumer, Centre de Géomorphologie, Centre National de la Recherche Scientifique, Rue des Tilleuls, 14000 Caen, France.

(Received December 7, 1988;

revised May 2, 1989.

accepted May 4, 1989.) 